\title{
YIELD DIFFERENTIALS AMONG PARTICIPATING AND NON-PARTICIPATING RICE FARMERS IN PUBLIC/PRIVATE PARTNERSHIP IN BENUE AND OGUN STATES, NIGERIA
}

\author{
Akinwale, J. A., A. A. Ladele and B.R. Olajide \\ Department of Agricultural Extension and Rural Development, University of Ibadan, Ibadan, \\ Nigeria. \\ E-mail: jonakinwale@yahoo.com
}

\begin{abstract}
The shortfall in domestic rice production in Nigeria has been attributed to inadequate provision of productivity-enhancing agricultural support services to rice farmers. Input supply and guaranteed market that entrenched the shortfall are the focus of the Public-Private Partnership (PPP) arrangement in rice production. The extent to which this has impacted on rice production was investigated in this study. Respondents totaling 235 from two rice producing states in Nigeria were purposively sampled. The respondents were further grouped into two, namely: participating farmers (PFs) and non-participating farmers (NPFs). Data relating to perception on enabling policy environment for PPP to thrive, level of access to agricultural support services, and yield from rice production were obtained from the respondents. Data were analysed using descriptive statistics, multiple regression analysis and chow test at á0.05. The results show that PFs had higher access to improved rice varieties, guaranteed market and extension services delivery than NPFs. The results of chow test show that the impacts of the explanatory variables were not the same across the two groups. Quantity of seeds and farm size contributed to reduction in quantum of yield gap for PFs, while farmers' age, access and timeliness of agricultural support services provision were for NPFs. Participating farmers had higher crop yield than non-participating farmers. Adequate supply of seeds aided the yield of participating farmers. Non-participating farmers had to utilize more quantity of fertilizers to have appreciable yield.
\end{abstract}

Keywords: Agricultural support services, Yield differentials, Rice production, Public-private partnership

\section{INTRODUCTION}

Nigeria has the potential to be self-sufficient in rice production as the country has an estimated 4.6 million hectares of land suitable for rice production, whereas only about 1.8 million hectares or $39 \%$ is currently developed for rice cultivation (National Rice Development Strategy, 2009). With average yield of 1.2 tons per hectare, rice production in Nigeria remains poor when compared with countries such as; India, 2.9; Pakistan, 3.0; China, 6.3; Egypt, 8.1; Vietnam, 4.2 and U.S.A., 7.0 [Food and Agricultural Organisation (FAO), 2010]. The consequence of this, is rice 
importation in order to bridge the gap from the domestic rice production in the country. According to Adesina (2013), a whopping sum of one billion naira is therefore being spent daily on rice importation. The implication of this is the neglect of the local rice farming, huge foreign exchange spending (which is a drain to the national economy), lack of food self-sufficiency and external dependence on food imports.

The situation in Nigeria, as in other developing countries, is that most of the productivity-enhancing agricultural support services (especially technology dissemination, information/extension, credit and finance) are largely provided by the public sector. However, the performance of the public sector in provision of these services and in reaching the poor small farmers has been generally unsatisfactory (NAERLS and PRSD, 2012). Huge costs and inherent inefficiencies in public sector management (largely due to lack of incentives) have been the key factors limiting wider access to these services. It should be noted that currently, the issue is not so much of availability, but of access to services and factors of production when and where they are needed. The key issue is: can these factors and services be provided through holistic approaches/mechanisms with the involvement of the private sector?

In the same vein, the trend in Nigerian agricultural value addition process is that of wide gap from farmers to processors and end-users; and there is no adequate and prompt information on market trends to control each of these activities appropriately. This obviously results in imbalance between demand and supply, causing either glut or scarcity (Sanni et al., 2009). It has become a common scene that while smallholder farmers are complaining of no market for their commodities, agroprocessors have insufficient raw materials, thus producing far less below their factory capacity. If effect, efforts targeted at enhancing smallholder farmers' productivity is essentially desirable.

It is against this background that this work situates within the framework of market liberalisation of the Federal Government through her Agricultural Transformation Agenda that encourages privatesector led and market-driven growth in rice production, processing and exporting. With this initiative and by contractual agreement, various public and private organisations are now pooling their resources, skills and expertise to ensure delivery of services along the rice value chain. A case of such is the United States Agency for International Development (USAID) that funded Maximising Agricultural Revenue and Key Enterprises in Targeted Sites (MARKETS) project in Benue state. Through this mechanism, both public and private institutions are into partnership arrangements aimed at improving the productivity of rice farmers in the state. The stakeholders are farmers (they are responsible for growing the specified rice varieties); Benue State Agricultural and Rural Development Authority (BNARDA) (the agency responsible for technology transfer); First Bank Nigeria Limited (disbursement of agricultural loans to participating farmers); Nigeria Agricultural Insurance Corporation (NAIC); (the body that provides crop insurance); OLAM Nigeria Limited (the miller that rolled out agricultural inputs and guarantee market to farmers); Benue State Ministry of Agriculture (supply of fertilizers at subsidised prices) and USAID/MARKETS (the agency responsible for capacity building). 
It is thus expected that the partnership would have impacted on the rice production in the state. It is on this premise that the study tends to compare the production performances of participating with that of non-participating rice farmers in Benue and Ogun states, Nigeria and as well as design location specific interventions. Thus, the objectives of the study are to: determine farmers' perception of enabling environment in rice production, ascertain farmers' access to agricultural support service in rice production in the study areas, identify determinants of yield gap between participating and non-participating rice farmers and compare factors that determine yield differentials between participating and non-participating farmers.

\section{METHODOLOGY}

\section{Research design}

Quasi experimental approach using with and without design was used for the study. The participating farmers (PFs) were drawn from Benue state and the non-participating farmers (NPFs) from Ogun State, Nigeria. The observed differences in the outcome variables between PFs and NPFs were considered as the effect of the partnership arrangement. The selection bias from this approach is minimized as the probability for economic agents with similar characteristics likely to be participants or non-participants is equal to zero (The two states were distinctly located from each other).

\section{Sampling procedure and sample size}

Multi-stage sampling procedure was used to select the respondents. For PFs, $25 \%$ of Local Government Areas participating in PPP in Benue state were selected through simple random sampling technique. Proportionate sampling technique was used to select $50 \%$ of cooperative societies (42) and $20 \%$ of members (170) were randomly selected. For NPFs, Ikenne zone was selected based on its level of rice production from the four agricultural zones in Ogun state. Using random and proportionate sampling techniques respectively, $50 \%$ of blocks (2) and cells (7) were selected. Then, $20 \%$ of rice farmers in selected cells were randomly chosen resulting in 65 NPFs. This gave a total sample size of 235

\section{Method of data collection}

Structured questionnaire was used to collect data on respondents' perception of policy environment in rice production, access to agricultural support services and yield.

\section{Analytical Techniques}

Regression Analysis

Yield Gap Model

The model is implicitly stated thus:

$Y g=f(X 1, X 2, X 3, X 4, X 5, X 6, X 7, X 8, X 9, X 10)$ 


$\begin{array}{lll}\text { Where } \mathrm{Yg} & = & \text { Yield gap in kg } \\ \text { X1 } & = & \text { Labour (mandays) } \\ \text { X2 } & = & \text { Quantity of seeds }(\mathrm{kg}) \\ \text { X3 } & = & \text { Farm size (ha) } \\ \text { X4 } & = & \text { Quantity of fertilizers }(\mathrm{kg}) \\ \text { X5 } & = & \text { Age (years) } \\ \text { X6 } & = & \text { Education attainment (years of formal education) } \\ \text { X7 } & = & \text { Farming experience (years) } \\ \text { X8 } & = & \text { Knowledge of production practices (actual scores) } \\ \text { X9 } & = & \text { Access to agricultural support services } \\ \text { X10 } & = & \text { Timeliness of agricultural support services }\end{array}$

The explicit form of the model is as below:

$\ln Y g=\beta 0+\beta 1 X 1+\beta 2 X 2+\beta 3 X 3+\beta 4 X 4+\beta 5 X 5+\beta 6 X 6+\beta 7 X 7+\beta 8 X 8$

$$
+\beta 9 \times 9+\beta 10 \times 10+\mu
$$

Three functional models were fitted for this analysis. Exponential regression model was chosen as the lead equation based on the significance of the individual explanatory variables as expressed by the t-statistic and the magnitude of the coefficient of determination (R2). Determinants of yield model among PFs and NPFs

The model is implicitly stated thus: $Y=f(X 1, X 2, X 3, X 4)$

Where $\mathrm{Y}=$ Yield in $\mathrm{kg}$

$\mathrm{X} 1=$ Farm size (ha)

$\mathrm{X} 2=$ Labour (manday)

$\mathrm{X} 3=$ Seeds $(\mathrm{kg})$

$\mathrm{X} 4=$ Fertilizers $(\mathrm{kg})$

The explicit form of the model is as follows: $\ln Y=\gamma_{0}+\gamma_{1} X_{1}+\gamma_{2} X_{2}+\gamma_{3} X_{3}+\gamma_{4} X_{4}+\varepsilon$

Three functional models were fitted to the production data. Meanwhile, exponential regression model was selected as the lead equation based on the significance of the individual explanatory variables as expressed by the t-statistic and the magnitude of the coefficient of determination $\left(R^{2}\right)$.

\section{Chow Test}

According to Damodar (2004), Chow test is used to examine structural or parameter stability of regression models. That is, to determine whether the independent variables have different impacts on different subgroups of the population. The test was therefore used to examine differences between data from the two groups (that is, PFs and NPFs).

The null hypothesis is

$\mathrm{HO}$ : There is parameter stability between the regression models for PFs and NPFs. 
Akinwale, Ladele \& Olajide

The Chow test is as follows:

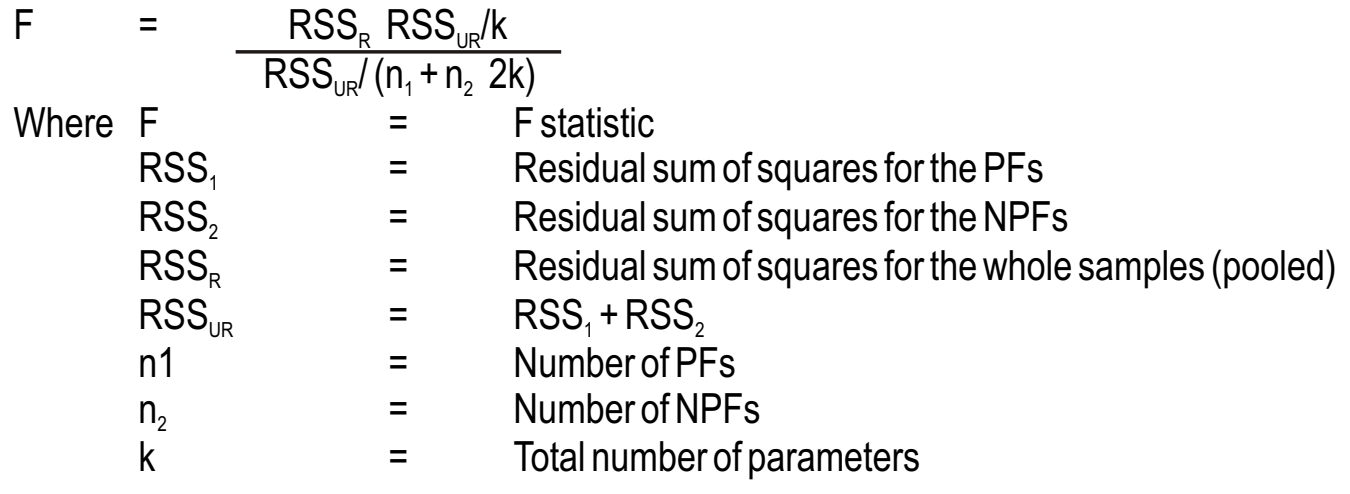

The decision rule is that if the $F$ statistic is greater than the $F$ tabulated, the null hypothesis of parameter stability should be rejected.

\section{RESULTS AND DISCUSSIONS}

\section{Farmers' perception of enabling policy environment in rice production}

Table 1 shows that the PFs found the policy on the facilitation of processing mills to be most favourable (4.32). This may be an indication that the PFs have used the PPP to identify processor who requires rice paddy to meet her raw material requirements. This is an improvement on earlier findings of Manyong, Ikpi, Olayemi et.al. (2005), in which they discovered policies geared towards enhanced postproduction activities to be generally ranked low by respondents in Nigerian agriculture. With this development, there is the opportunity for value addition in an effort to improve the competiveness of domestic rice with imported rice.

Next favourable to the above in rank is that innovation of inputs, techniques of production were rightly disseminated (4.25) and that there is good linkage/networks with input suppliers (4.05). With these developments, the input market among the PFs is thus expected to perform better as the favourable policy environment will stimulate farmers' access to production inputs. This agrees with Shepherd (2007), in which he found that partnership with farmers can only bring positive impact if only the enabling environment as provided by the government is appropriate for development of market linkages.

Meanwhile, the farmers perceived that the policy environment had been unfavourable for the ratio of extension agent to farmer (1.66), adequate provision of credit (1.81) and provision of infrastructure and support system such as roads, storage facilities, and irrigation system (2.02). Meanwhile, the table shows that the NPFs found all the 12 policy statements unfavourable as seen from the low mean scores. It can then be implied from these findings that the policy environment in Ogun state is still far from being able to boost domestic rice production in order to curtail unfair competition from imported rice. 


\section{Farmers access to agricultural support services and provisions}

The respondents' access to agric-support services in table 2 shows that on the whole, PFs had better access to all the components of agric-support services when compared with NPFs. For instance, PFs had high access $(\bar{X}=1.83)$ to provision of improved rice varieties than the NPFs $(\bar{X}$ $=0.03$ ). The high access of PFs to improved rice varieties is not surprising as the purchase of rice paddy by OLAM is on the premise of growing the specified rice varieties. This must have invariably served as incentive for the farmers to grow the improved rice varieties as they are sure of market for their output. Thus, unlike the NPFs who rely on planting left-overs from the previous harvest, the PFs are expected to experience increase in rice yields.

Similarly, table 2 shows that PFs had high access ( $\bar{X}=1.75)$ to the provision of buy-back arrangement than the NPFs ( $\bar{X}=0.97$ ). The result suggests that the farmers in the partnership arrangement are better linked to the markets than their non-partnership counterpart. This is a great improvement to the current situation in Nigeria and other sub-Saharan Africa where majority of farmers lack access to reliable produce markets. Wiggis and Keats (2013) found that $25 \%$ of small holder farmers in sub-Saharan Africa suffer from market failure as they are not linked to markets for a variety of reasons such as remoteness and low production. Further to this development, the participating farmers are expected to be motivated to go into rice production as they are sure that their produce will be bought by the processor.

Also, table 2 shows that PFs had high access $(\bar{X}=1.62)$ to extension services delivery in rice production than NPFs $(\bar{X}=0.55)$. This implies that the partnership arrangement has made agricultural extension services to be more accessible to the PFs than NPFs. This finding is corroborated by the submission of Nambiro, Omiti and Mugunieri (2005) that partnerships arrangement involving farmers' organisations in Kenya has increased both the awareness and access of the farmers to agricultural extension services. Thus, the PFs are thus expected to be more informed on modern practices and technologies in rice production than the non-participating farmers.

Table 2 further shows that the PFs had high access $(\bar{X}=1.41)$ to fertilizers supply than the NPFs $(\bar{X}=0.80)$. This result indicates that the partnership arrangement has improved fertilizer's access to partnership farmers. Thus, the PPP arrangement then appears to be a step in right direction toward addressing the unavailability and monopolistic nature of middle men which has made this input always inaccessible to Nigerian farmers (Babatunde and Boluwade, 2004). This level of access to fertilizers may thus increase the yields and income of participating farmers than their non-participating counterparts. 


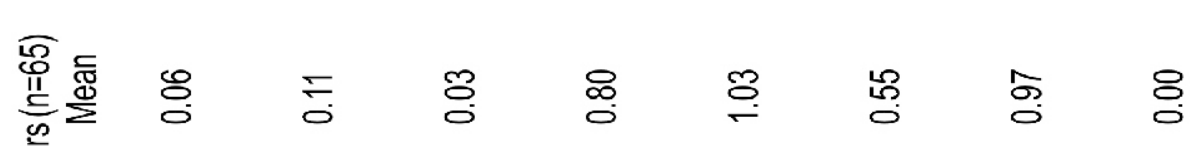
壱 高突

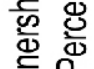

壳

产离

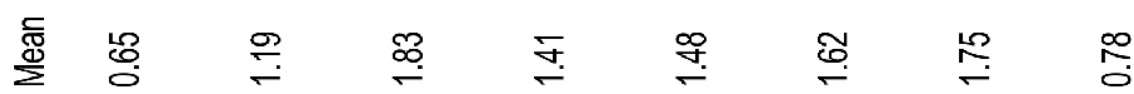

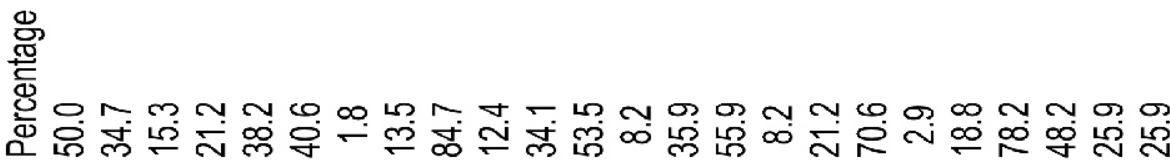

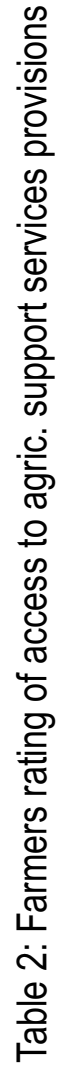

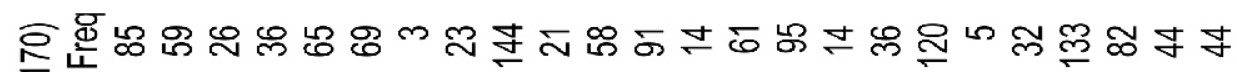
$\stackrel{\text { II }}{5}$

$\frac{5}{5} \quad \frac{1}{2}$

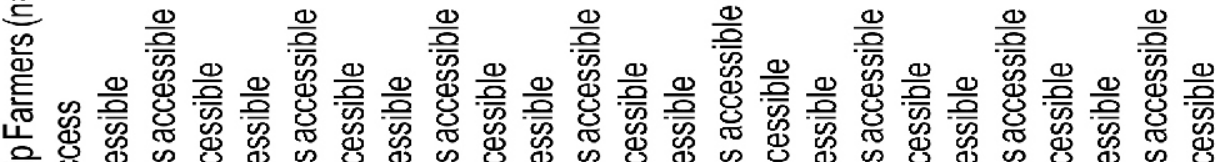
运

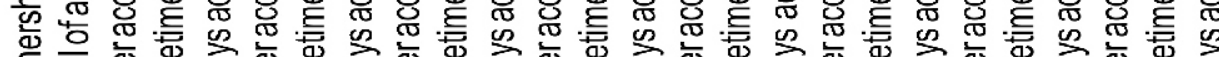

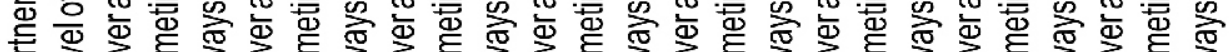

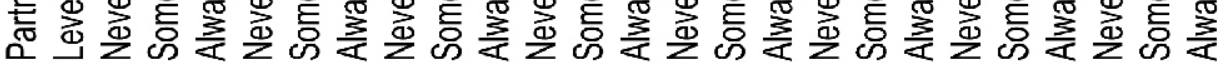

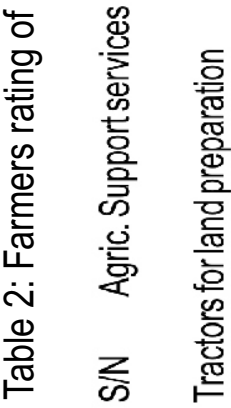

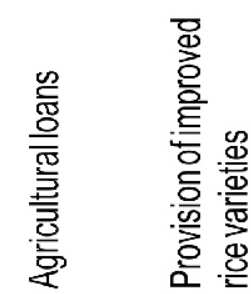

궁

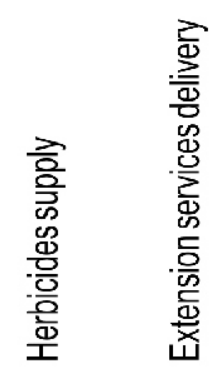

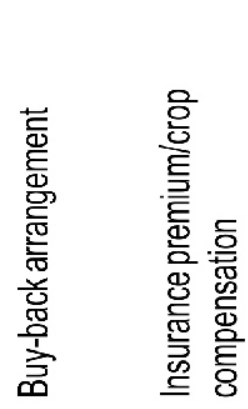

六 


\section{Determinants of yield gap among PFs and NPFs}

The model of factors affecting rice yield among the rice farmers is presented in Table 3 . The result revealed that seeds, age, education, experience and access to agricultural support services had negative signs among PFs. This suggests that, increase in these variables will result into reduction in yield gap in rice production and vice versa. Nevertheless, it was quantity of seeds that was found to be statistically significant out of the aforementioned variables. This implies that increase in quantity of seeds narrowed the yield gap among the PFs. This effect may be attributed to the fact that increase in seeds has the tendency to increase the plant population and farm output and eventually reduce the yield gap. This result disagrees with Akintayo, Rahji, Awoyemi, et. al. (2011) who discovered that seeds had no significant effects on closing yield gap in lowland rice production in North-Central, Nigeria. Similarly, farm size was the only variable found to be statistically significant out of the other variables (labour, fertilizers, experience, knowledge and timeliness) that had positive sign. This indicates that increase in farm size increased the yield gap among the PFs. It then suggests that with proper land management and by utilizing appropriate yield increasing technologies the PFs may need not increase their land areas in order to bridge the yield gap.

Table 3: Result of Exponential Model for Yield Gap of Pfs

\begin{tabular}{|c|c|c|c|c|c|}
\hline Variables & Unstan & d coefficien & Standardized coefficient & $\mathrm{t}$ & Sig. \\
\hline$P F n=170$ & B & Std. Error & Beta & & \\
\hline Constant & 1.940 & 0.819 & & 2.370 & 0.019 \\
\hline Labour & 0.001 & 0.000 & 0.035 & 0.176 & 0.861 \\
\hline Seeds & -0.002 & 0.000 & -1.133 & -5.275 & $0.000^{*}$ \\
\hline Farm Size & 0.102 & 0.022 & 1.097 & 4.544 & $0.000^{*}$ \\
\hline Fertilizers & 0.008 & 0.000 & 0.116 & 0.719 & 0.473 \\
\hline Age & -0.001 & 0.004 & -0.024 & -0.242 & 0.809 \\
\hline Education & -0.010 & 0.006 & -0.128 & -1.615 & 0.108 \\
\hline Experience & -0.006 & 0.005 & -0.116 & -1.128 & 0.261 \\
\hline Knowledge & 0.046 & 0.042 & 0.079 & 1.094 & 0.276 \\
\hline Access & -0.586 & 0.677 & -0.159 & -0.866 & 0.388 \\
\hline Timeliness & 0.905 & 0.635 & 0.261 & 1.426 & 0.156 \\
\hline
\end{tabular}

$R=0.480 R^{2}=0.231$ Adjusted $R^{2}=0.182$ *Significant at $p=0.05$

Source: Field survey, 2012

Among the NPFs, Table 4 further shows that labour, seeds, age, knowledge and access to agricultural support services had negative signs. This suggests that, increase in these variables will result into reduction in yield gap in rice production and vice versa. Meanwhile, it was only age and access to agricultural support services that were found to be statistically significant on yield gap. This result implies that the yield gap among the NPFs would be reduced as the farmers get older. This result runs in contrast with the findings of Kamruzamman, Ahmed and Bashar (2001) that found that farmers' age had positive significant effect on yield gap and technical efficiency of paddy 
production in Commilla district of Bangladesh. Also, increase in NPFs access to agricultural support services had significant effect on the yield gap. This implies that with the adequate access, the farmers would be able to adopt improved technologies that would narrow the yield gap. Meanwhile, other variables such as farm size, fertilizers, education, experience and timeliness of agricultural support services came out with positive signs among the NPFs. This suggests that, increase in these variables will widen the yield gap in rice production. Nonetheless, out of the listed variables, it was the timeliness of support services that was statistically significant. This suggests that timeliness of agricultural support services is likely to increase the yield gap and subsequently low yield for NPFs. This may be as a result of inadequate monitoring or poor resources allocation of the agricultural support services provision that were available to the farmers. This is consistent with Nosiru, et.al. (2014) who found rice farmers in Kaduna State to be inefficient in both managerial and technical allocation of resources in NERICA production.

Table 4: Result of Exponential Model for Yield Gap of NPFs

\begin{tabular}{|c|c|c|c|c|c|}
\hline \multirow{2}{*}{$\begin{array}{l}\text { Variables } \\
\text { NPF } n=65\end{array}$} & \multicolumn{2}{|c|}{ Unstandardized coefficient } & \multirow{2}{*}{$\begin{array}{l}\text { Standardized coefficient } \\
\text { Beta }\end{array}$} & \multirow[t]{2}{*}{$\mathrm{T}$} & \multirow[t]{2}{*}{ Sig. } \\
\hline & B & Std. Error & & & \\
\hline Constant & 3.113 & 0.274 & & 11.364 & 0.000 \\
\hline Labour & -0.004 & 0.000 & -2.227 & -1.016 & 0.314 \\
\hline Seeds & -0.002 & 0.002 & -1.260 & -1.510 & 0.137 \\
\hline Farm Size & 0.346 & 0.230 & 3.219 & 1.508 & 0.137 \\
\hline Fertilizers & 0.000 & 0.001 & 0.153 & 0.337 & 0.738 \\
\hline Age & -0.008 & 0.004 & -0.446 & -2.068 & $0.043^{*}$ \\
\hline Education & 0.002 & 0.010 & 0.025 & 0.163 & 0.871 \\
\hline Experience & 0.002 & 0.004 & 0.110 & 0.538 & 0.592 \\
\hline Knowledge & -0.006 & 0.014 & -0.054 & -0.428 & 0.671 \\
\hline Access & -2.976 & 1.543 & -1.125 & -1.929 & $0.050^{*}$ \\
\hline Timeliness & 3.181 & 1.564 & 1.196 & 2.033 & $0.047^{*}$ \\
\hline
\end{tabular}

$R=0.515 R^{2}=0.265$ Adjusted $R^{2}=0.129 *$ Significant at $p=0.05$

Source: Field survey, 2012

Table 5 also shows the regression results from the pool data. It is evident from the result that the coefficient of labour was positive and not statistically significant in explaining the yield gap of rice farmers in the two groups. The coefficient of seeds was negative and statistically significant which indicates that keeping other factors constant, a unit increase in quantity of seeds would result in a decrease in yield gap by 0.002 . This result suggests that adequate supply of seeds has the tendency to close the yield gap among the farmer groups. Also, the coefficient of farm size was positive and statistically significant. This means that while keeping other factors constant, a unit increase in farm size will increase the yield gap by 0.102 . It then becomes imperative to ensure adequate utilization of land area by the farmers through adoption of innovative techniques rather 
than expanding the land area without corresponding technical competence. Furthermore, the coefficient of fertilizers and timeliness of agricultural support services from Table 5 were positive and statistically not significant.

Table 5: Result of the Exponential Model for Yield Gap of PFs and NPFs

\begin{tabular}{llllcc}
\hline $\begin{array}{l}\text { Variables } \\
\text { PFs+NPFs }\end{array}$ & $\mathrm{n}=\begin{array}{l}\text { Unstandardized coefficient } \\
\text { 235 }\end{array}$ & $\begin{array}{l}\text { Standardized coefficient } \\
\text { Beta }\end{array}$ & $\mathrm{T}$ & Sig. \\
\hline Constant & 3.056 & 0.190 & & & \\
Labour & 0.002 & 0.000 & 0.067 & 16.090 & 0.000 \\
Seeds & -0.002 & 0.000 & -1.177 & 0.488 & 0.626 \\
Farm Size & 0.102 & 0.018 & 1.103 & -6.483 & $0.000^{*}$ \\
Fertilizers & 0.009 & 0.000 & 0.121 & 5.760 & $0.000^{*}$ \\
Age & -0.003 & 0.003 & -1.116 & 0.999 & 0.319 \\
Education & -0.007 & 0.005 & -0.092 & -1.215 & 0.226 \\
Experience & -0.001 & 0.003 & -0.022 & -1.350 & 0.178 \\
Knowledge & -0.008 & 0.011 & -0.070 & -0.226 & 0.822 \\
Access & -0.882 & 0.560 & -0.405 & -0.764 & 0.446 \\
Timeliness & 1.020 & 0.532 & 0.459 & -1.576 & 0.116 \\
\hline
\end{tabular}

$\mathrm{R}=0.452 \mathrm{R} 2=0.204$ Adjusted $\mathrm{R} 2=0.169$ *Significant at $\mathrm{p}=0.05$

Source: Field survey, 2012

The Chow test: The result of the Chow test in Table 6 revealed that the calculated F-statistic value of 0.77 was less than the table value of 1.88 at $a=0.05$. Therefore, the null hypothesis was accepted in favour of parameter stability. This implied that the impacts of the explanatory variables (i.e. quantity of seeds and farm size) were the same across the two groups. It then implies that adequate quantity of seeds and farm size are essentials for closing yield gap and increased rice yield for both PFs and NPFs.

Table 6: Chow Test Results for Yield Gap Analysis

\begin{tabular}{llllcl}
\hline RSS1 & RSS2 & RSSR & F stat. & F tab @ $p \leq 0.05$ significant level & Decision \\
\hline 22.198 & 2.593 & 25.771 & 0.765 & 1.88 & Accept Null \\
\hline
\end{tabular}

Source: Field survey, 2012

\section{Factors of yield differentials among PFs and NPFs}

The production model estimation using exponential regression analysis is presented in Table 7. The result revealed that among the PFs, all the independent variables had positive sign but only quantity of seeds was statistically significant. The coefficient of seeds was positive which 
indicates that keeping other factors constant, a unit increase in quantity of seeds would result in increase in yield by 0.003 . This result corroborated the findings of Rahii and Omotesho (2006) in which seed was found as the largest contributor to rice production among rice farmers in Niger state, Nigeria.

Table 7: Result of Exponential Yield Model for Pfs

\begin{tabular}{llllll}
\hline Variables & \multicolumn{2}{l}{ Unstandardized coefficient } & Standardized coefficient & $\mathrm{T}$ & Sig. \\
$\mathrm{PF} n=170$ & $\mathrm{~B}$ & Std. Error & Beta & & \\
\hline Constant & 8.359 & 0.044 & & 187.897 & 0.000 \\
Farm size & 0.018 & 0.023 & 0.096 & 0.783 & 0.435 \\
Labour & 0.003 & 0.001 & 0.047 & 0.459 & 0.647 \\
Seeds & 0.003 & 0.001 & 0.652 & 6.076 & $0.000^{*}$ \\
Fertilizers & 0.000 & 0.000 & 0.110 & 1.359 & 0.176 \\
\hline
\end{tabular}

$\mathrm{R}=0.878 \mathrm{R} 2=0.770$ Adjusted $\mathrm{R} 2=0.765^{\star}$ Significant at $\mathrm{p}=0.05$

Source: Field survey, 2012

Table 8 also shows the results for the NPFs. The coefficient of seeds was negative and statistically significant which indicates that keeping other factors constant, a unit increase in quantity of seeds would result in a decrease in yield by 0.006 . This result suggests that adequate seeds supply will reduce the yield of NPFs. This result may be because the farmers planted seeds that were not certified making them have higher seed rate but without the anticipated yield. Also, the coefficient of fertilizers was positive and statistically significant for NPFs. This shows that while making other factors constant, a unit increase in fertilizers would result in increase in yield by 0.001 .

Table 8: Result of Exponential Yield Model for NPFs

\begin{tabular}{|c|c|c|c|c|c|}
\hline \multirow{2}{*}{$\begin{array}{l}\text { Variables } \\
\text { PF } n=65\end{array}$} & \multicolumn{2}{|c|}{ Unstandardized coefficient } & \multirow{2}{*}{$\begin{array}{l}\text { Standardized coefficient } \\
\text { Beta }\end{array}$} & \multirow[t]{2}{*}{$\mathrm{t}$} & \multirow{2}{*}{ Sig. } \\
\hline & B & Std. Error & & & \\
\hline Constant & 7.010 & 0.077 & & 90.863 & 0.000 \\
\hline Farm size & 0.381 & 0.308 & 1.234 & 1.236 & 0.221 \\
\hline Labour & 0.002 & 0.000 & 0.384 & 0.388 & 0.699 \\
\hline Seeds & -0.006 & 0.002 & -1.199 & -2.940 & $0.005^{*}$ \\
\hline Fertilizers & 0.002 & 0.001 & 0.436 & 1.897 & $0.043^{*}$ \\
\hline
\end{tabular}

$\mathrm{R}=0.872 \mathrm{R} 2=0.760$ Adjusted $\mathrm{R} 2=0.744{ }^{*}$ Significant at $\mathrm{p}=0.05$

Source: Field survey, 2012

The results in Table 9 further revealed that for the pool data, all the independent variables had positive sign except labour. Farm size, fertilizer, and seeds had positive signs which mean increase in the concerned variables resulted in increase in yield and vice versa. This is consistent with 
Akinbode (2013) who discovered that farm size, fertilizers and seeds were among the factors of production that increased output of rice among farmers in Niger State, Nigeria. The negative coefficient of labour which was statistically significant indicates that increase in labour would result in decrease in rice yield. This may mean that there was an excessive and ineffective use of labour and thus a decrease in labour utilization may result in increase in yield. This is consistent with Omotesho, Muhammad-Lawal and Yusuf (2010) who found that amount of labour used was inversely related to the output of rice farmers in Kwara State, Nigeria.

Meanwhile, in the regression models for PFs, NPFs and Pooled data, seeds (0.62), farm size (1.23) and seeds (0.43) had the largest absolute standardized coefficients respectively. This means that these explanatory variables contributed the most to the models.

Table 9: Result of Exponential Yield Model for PFs and NPFs

\begin{tabular}{lcccrl}
\hline $\begin{array}{l}\text { Variables } \\
\text { PFs+NPFs }\end{array} \quad \begin{array}{c}\text { Unstandardized coefficient } \\
\text { 235 }\end{array}$ & B & Std. Error & $\begin{array}{l}\text { Standardized coefficient } \\
\text { Beta }\end{array}$ & $t$ & Sig. \\
\hline Constant & 8.018 & 0.053 & & & \\
Farm size & 0.083 & 0.028 & 0.346 & 152.346 & $0.000^{*}$ \\
Labour & -0.002 & 0.000 & -0.297 & 3.013 & $0.003^{*}$ \\
Seeds & 0.002 & 0.001 & 0.431 & -3.909 & $0.000^{*}$ \\
Fertilizers & 0.001 & 0.000 & 0.344 & 3.926 & $0.000^{*}$ \\
\hline
\end{tabular}

$\mathrm{R}=0.825 \mathrm{R} 2=0.680$ Adjusted $\mathrm{R} 2=0.675^{*}$ Significant at $\mathrm{p}=0.05$

Source: Field survey, 2012

The Chow test: The result of the Chow test from Table 10 revealed that the calculated Fstatistic value of 50.89 was greater than the table value of 3.04 at $a=0.05$. Therefore, the null hypothesis was rejected against parameter stability. This implied that the impacts of the explanatory variables (i.e. farm size, labour quantities of seeds and fertilisers) were not the same across the two groups. This could be corroborated from the higher yields obtained by the PFs. While quantity of seeds increased PFs yield, it was quantity of fertilisers that did for NPFs.

Table 10: Chow Test Results for Yield Model

\begin{tabular}{llllcl}
\hline RSS1 & RSS2 & RSSR & F cal. & $F$ tab @ $p \leq 0.05$ significant level & Decision \\
\hline 26.322 & 6.972 & 70.947 & 50.89 & 3.04 & Reject Null \\
\hline
\end{tabular}

Source: Field survey, 2012 


\section{CONCLUSION}

The policy environment is found to be enabling for public-private partnership to thrive in Benue state. This situation has impacted favourably on the interaction among the various actors in the partnership arrangement. This improved interaction has ensured improved access of participating farmers to agricultural support services as compared to the non-participating farmers. Parameters such as quantity of seeds and fertilizers aided the yield of participating farmers and non-participating farmers respectively. Thus, location specific interventions should be put in place to strengthen adequate delivery of these inputs to ensure increase rice yield.

\section{REFERENCES}

Adesina A. (2013). Before Banning Rice Importation. Retrieved December 13th, 2013 from http://www.punchng.com/editorial/before-banning-rice-importation.

Akinbode, S.O. (2013). "Access to Credit: Implication for Sustainable Rice Production in Nigeria". Journalof Sustainable Development in Africa 15 (1):13-30.

Akintayo, O.I., M.A.Y. Rahji, T.T. Awoyemi and A.I. Adeoti (2011). "Determinants of Yield Gap in Lowland Rice Production in North-Central, Nigeria". Agrosearch 11 (1 \&2):1-10.

Babatunde R.O. and E.O. Boluwade (2004). "Resource Use Efficiency in Food Crop Production in Ekiti State Nigeria". Journal of Agriculture and Social Research 4 (1):105-117

Damodar N.G. (2004). Basic Econometrics. Tata McGraw-Hill Publishing Company Limited. Fourth edition.

Food and Agricultural Organisation (2010). Climate Change Implications for Food Security and Natural Resources Management in Africa. Twenty six regional conference for Africa held at Luanda,Angola, 3-7 May, 2010.

Jose S. (2014). Innovation in Agriculture: A Key process for sustainable development. Retrieved on June 23rd 2015 from

Http://www.iica.int/Esp/Programas/Innovacion/Documentos\%20de\%20Tecnologa\%20e \%20Ina n/Innovation_PP_En.pdf

Kamruzamman M., A. Ahmed and M. Bashir (2001). "Effect of Credit on Yield Gap and Technical Efficiency of Boro paddy Production in a Selected Area of Commilla District of Bangladesh". Bangladesh Journal of Agricultural Economics 25 (1):113-126

Ladele A.A. and A. Aderinto (2014). "Effectiveness of Market Support Services on Productivity of Cassava Farmers in South Western Nigeria". Journal of Agriculture and Rural Development 12(1):1-17.

Lesley D. (2014). How do smallholder farmers access information. Retrieved on June 24th , 2015 from http://www.cgap.org/blog/how-do-smallholder-farmers-access-information

Manyong, V.M., A. Ikpi, J.K. Olayemi, S.A. Yusuf, B.T. Omonona, V. Okoruwa, and F.S. Idachaba. (2005). Agriculture in Nigeria: Identifying Opportunities for Increased Commercialization and Investment. IITA, Ibadan, Nigeria. 159p. 
NAERLS and PRSD (2012). Agricultural Performance Survey Report of 2012 Wet Season in Nigeria. NAERLS Press. 221p.

Nambiro E., J. Omiti and L. Mugunieri (2005). "Decentralisation and Access to Agricultural Extension Services in Kenya". Strategies and Analysis for Growth and Access (SAGA) working paper. 70pp.

Nosheen, F., T. Ali and M. Ahmad (2010). "Analysis of Gender Specific Sources of Information Regarding Home and Farm Practices in Potohar region: A case study". The Journal of Animal Plant Science 20(1): 56-59.

Nosiru, O.M.O., Rahji, M.A.Y., Ikpi, A.E. and Adenegan, K.O. (2014). "Scale Efficiency and Determinants of productivity of New Rice for Africa (NERICA) farmers in Kaduna state, Nigeria". Agrosearch 14 (2): 113-128.

OECD 2013. Agricultural Innovation Systems: A Framework for Analysing the Role of the Government.OECD Publishing. Retrieved on March 12th, 2015 from http://dx.doi.org/10.1787/9789264200593-en.

Rahji, M.A.Y. and O.A. Omotesho (2006). "Technical Inefficiency and Competitiveness in Production: the case of rice farmers in Niger State, Nigeria". Agrosearch 8 (1):67-79.

Sanni, L. O., O. O. Onadipe, P. Ilona, M. D. Mussagy, A. Abass and A. G. O. Dixon 2009. Successes and challenges of cassava enterprises in West Africa: a case of Nigeria, Benin and Sierra Leone. IITA, Ibadan, Nigeria. 19pp

Shepherd A.W. (2007). Approaches to linking producers to markets. A review of experience to date. Agricultural Management, Marketing and Finance. Occasional Paper 13, Rome Food and Agriculture Organisation of the United Nations.

Wiggis, S. And S. Keats (2013). Leaping and Learning Linking smallholders to markets. Agriculture for impact. Imperial College London. 15 Prices Gardens, South Kensington Campus, London, SW 7 INA223p.

World Bank (2007). Enhancing Agricultural Innovation: How to Go Beyond the Strengthening of Research Systems. Washington, DC: World Bank. Retrieved on April 2nd, 2015 from https://openknowledge.worldbank.org. 